\title{
Costus root aqueous extract modulates rat liver toxicity, DNA damage, injury, proliferation alterations induced by plant growth regulator Ethephon
}

\author{
Ehab Tousson ${ }^{\circledR *}$, Afaf El-Atrsh, Merfaat Mansour, Abdallah Assem \\ Zoology Department, Faculty of Science, Tanta University, Egypt
}

\begin{abstract}
Ethephon $($ Ethrel $\mathbb{R})$ is an ethylene-based plant growth regulator that used in agriculture and it has direct and indirect effects on human health, direct effect via its inhalation during usage in agriculture and indirect effect through the diet (Fruits and vegetables) that is sprayed with it. The current study aimed to examine the possible modifying effects of costus (Saussurea lappa) root aqueous extract against Ethephon induced liver toxicity, injury, DNA fragmentation and PCNA alterations in male rats. Fifty adult male rats were divided into 5 groups (1st, control; 2nd, Costus; 3rd, Ethephon; 4th, Post treated Ethephon with costus; 5th, self-healing Ethephon). Current results revealed that; a significant increase in aspartate transaminase (AST), alanine transaminase (ALT), alkaline phosphatase (ALP), liver injury, DNA damage and PCNA expressions in Ethephon group when compared with control group. In contrast; a significant decrease in albumin and total proteins in Ethephon group when compared with control group. Treatment of rats with costus after Ethephon improved these alterations as compared with Ethephon self-healing. So, it could be concluded that costus root extract worth to be considered as a natural substance for ameliorating the hepatic toxicity induced by plant growth regulator Ethephon.
\end{abstract}

Keywords: Plant growth regulator. Ethephon. Costus. Liver. DNA damage. PCNA expression. Rat.

\section{INTRODUCTION}

Plant growth regulators are organic compounds which are registered for use in agriculture, affect variant physiological processes of plants and are commonly active at very low concentrations (Wani et al., 2017; Hajam et al., 2017, 2018). Ethephon (2-chloroethylphosphonic acid; Ethrel ${ }^{\circledR}$ ) is an ethylenebased plant growth regulator that used in agriculture and it has direct and indirect effects on agricultural and industrial workers, direct as through its inhalation during usage in agriculture and indirect through the diet (Fruits and vegetables) which sprayed with it (Pierik et al., 2006; Taheri et al., 2012; Moustakime et al., 2018).

\footnotetext{
*Correspondence: E. Tousson, Zoology Department, Faculty of Science, Tanta University Egypt. Phone: 00201002282382. Email: toussonehab@ yahoo.com, ehabtousson@science.tanta.edu.eg
}

Several dietary studies have been conducted on ethephon toxicity on experimental animals as rats, mice and rabbits (Tuluce, Celik, 2006; Abd El Raouf, Girgis, 2011; Anant, Avinash, 2012). Using Ethephon alone or combined with other pesticides have been reported to induce damage to liver and kidney of mice (Yazar, Baydan, 2008).

Many herbal plants extracts and their products have been used for treatment of several fateful diseases (Moustafa et al., 2014; Saggu et al., 2014; Tousson et al., 2016, Tousson et al., 2018). Costus or Saussurea Lappa is one of these herbal plants that is rich with antioxidant and widely utilized in various indigenous system of medicine all around the world for treatment variety of disorders for instance diarrhea, tenesmus, dyspepsia, vomiting, inflammation (Xiao et al., 2006; Irshad, Mahmood, Perveen, 2012). Saussurea Lappa has been screened for different pharmacological activities and been proved for activities like anti-oxidant activity (Chang, Choi, 
Kum, 2012), anti-hepatotoxic activities (Yaeesh et al., 2010), anti-diabetic (Upadhyay et al., 1996), anti-fungal effect (Barrero et al., 2000), anthelmentic (Seki et al., 1991), anti-tumour (Ko et al., 2005), anti-inflammatory (Yashvanth et al., 2010), anti-ulcer (Sutar et al., 2011), anti-microbial (Khalid et al., 2011) and immunostimulant activities (Hamilton et al., 2004).

The knowledge concerning the combined toxicity effects of plant growth promoters or Ethephon on the mammals is limited. Therefore the current study was conducted to examine the possible modifying effects of costus (Saussurea lappa) root aqueous extract against liver toxicity, injury, DNA fragmentation and PCNA marker alterations induced by Ethephon in male rats.

\section{MATERIALS AND METHODS}

\section{Chemical and reagent}

- Costus: Saussurea lappa absolute, CAS Number: 8023-88-9, Robertet, Inc., France.

- Ethephon: Sigma-Aldrich Chemie GmbH (Riedstrasse 2D-89555 STEINHEIM) Product Number: C0143 Sigma Index-No.: 015-154-00-4 CAS-No.:16672-87-0

\section{Experimental animals}

The experiment was performed on 50 male albino Sprague-Dawley rats that were weighing $150 \mathrm{~g}( \pm 10)$ and of 10-12 weeks age. They were acquired from laboratory farms, Zoology Department, Faculty of Science, Tanta University, Egypt. The rats were held in suitable plastic cages for one week before the experimental work for acclimation with a new room conditions and maintained on a standard rodent diet and water available ad libitum. The temperature in the animal room was adjusted to $23 \pm 2{ }^{\circ} \mathrm{C}$ with a relative humidity of $55 \pm 5 \%$. Light was on a $12 \mathrm{~h}$ light/dark cycle. Animal procedures were performed in accordance with the Ethics Committee of the National Research Centre, Egypt.

\section{Experimental groups}

A total of 50 rats were equally divided into five groups (10 rats each). 1st group, Control group included rats received no treatment; 2 nd group, Costus group included rats received by oral gavages Costus extract $(50 \mathrm{mg} / \mathrm{kg}$ body weight/2day) for four weeks (Arhoghro et al., 2015); 3rd group, Ethephon group included rats that injected oral gavages with Ethephon (200 mg/kg body weight/day) for four weeks (Bhadoria et al., 2015); 4th group, post-treated group included rats that received Ethephon $(200 \mathrm{mg} / \mathrm{kg}$ body weight/day) for four weeks and then received costus $(50 \mathrm{mg} / \mathrm{kg} / 2$ day) orally for another four weeks; 5 th group, Self-healing group included rats that received Ethephon ( $200 \mathrm{mg} / \mathrm{kg}$ body weight/day) for four weeks and then left for another four weeks without receiving any treatment.

At the end of the experimental period, rats were fasted overnight; rats were euthanized with intraperitoneal injection with sodium pentobarbital and subjected to a complete necropsy. Blood samples were individually collected from the inferior vena cava of each rat in non heparinized glass tubes for estimation of liver functions (ALT, AST, total protein, albumin and ALP).

\section{Liver function in serum}

Serum alanine transaminase (ALT) and serum aspartate transaminase (AST) activities were evaluated by the colorimetric assay using commercial kits supplied by (Biodiagnostic, Egypt) in accordance to the assay designated by Reitman and Frankel, (1957). Estimation of albumin Concentration was performed by using commercial kit that was purchased from Diamond, Egypt. Estimation of albumin Concentration was assessed in accordance to the assay designated by Doumas et al. (1971). Estimation of total protein concentration was assessed by using commercial kit that was purchased from Diamond, Egypt. Estimation of total protein concentration was assessed in accordance to the assay designated by Bradford (1976). Serum alkaline phosphatase activity was analysed by using commercial kit that was supplied by BioMérieux Co, from France (Belfield, Goldberge, 1971).

\section{Performance of comet assay to identify DNA damage in hepatic tissue}

DNA damage analysis and quantification were conducted with the comet assay (single cell gel electrophoresis) method. $100 \mathrm{mg}$ samples of liver were obtained from every experimental group and subjected to mincing in chilled homogenising buffer consisting of $0.075 \mathrm{M} \mathrm{NaCl}$ and $0.024 \mathrm{M}$ Na2EDTA, before undergoing gentle homogenisation with the use of a homogeniser (Ikemoto Scientific Technology Company Ltd., Japan) in ice. A suspension of cells was subjected to 10 -minute $700 \mathrm{X}$ g centrifugation at $4{ }^{\circ} \mathrm{C}$, followed 
by re-suspension in cold buffer. An epifluorescence microscope permitted visualisation of the slides. The DNA migration length (comet tail length) caused by genotoxicity was established by scanning digital images in an image analyser (Comet $\mathrm{V}$ image analyser software), in the case of the control and Ethephon groups. Furthermore, observation of a minimum of 505 arbitrarily chosen cells per sample enabled determination of tail length (TL), representing the distance between the comet head and the final signal in the tail that could be seen, the DNA tail intensity (TI), representing the DNA fraction in the tail divided by the DNA quantity in the nucleus multiplied by 100 , and the DNA tail moment (TM), representing the product of the DNA quantity in the tail and TL. Every assay was carried out thrice and contrasted against control.

\section{Histopathological investigation}

Immediately after decapitation animals were dissected, liver from different groups were quickly removed, washed in 0.9 saline solutions and fixed in $10 \%$ neutral buffered formalin. After fixation, specimens were dehydrated in an ascending series of alcohol, cleared in two changes of xylene and embedded in molten paraffin (mp. $50-58{ }^{\circ} \mathrm{C}$ ). Sections of 7 micra thickness were cut using rotary microtome and mounted on clean slides. Sections were stained with Ehrlich's haematoxylin and counterstained with eosin as a routine method after (Tousson, 2016).

\section{Liver regeneration analysis}

Proliferating cell nuclear antigen immunoreactivity (PCNA-ir) was performed according to Tousson et al. (2011, 2012). Distribution of PCNA stained nuclei were examined in deparaffinized sections $(5 \mu \mathrm{m})$ using an Avidin-Biotin-Peroxidase immunohistochemical method (Elite-ABC, Vector Laboratories, CA, USA) with PCNA monoclonal antibody (dilution 1:100; DAKO Japan Co, Tokyo, Japan).

\section{Statistical analysis}

Data were expressed as mean values $\pm \mathrm{SE}$ and statistical analysis was performed using one way ANOVA to assess significant differences among treatment groups. The criterion for statistical significance was set at $\mathrm{p}<0.01$ for the biochemical data. All statistical analyses were performed using SPSS statistical version 21 software package (SPSS ${ }^{\circledR}$ Inc., USA).

\section{RESULTS}

Table I shows that serum ALT, AST and alkaline phosphatase (ALP) were significantly increased in Ethephon group when compared with control and costus groups. This elevation decreased in post-treated and self-healing groups when compared with Ethephon group. On the other hand, albumin and total protein were significantly decreased in Ethephon group when compared with control and costus groups. Serum

TABLE I - Changes in liver functions in different groups

\begin{tabular}{lccccc}
\hline & G1 & G2 & G3 & G4 & G5 \\
\hline ALT (U/L) & $29.6^{\#} \pm 1.166$ & $32.4^{\#} \pm 2.135$ & $105.8^{*} \pm 3.308$ & $46.2^{\# *} \pm 2.478$ & $53.4^{\# *} \pm 1.166$ \\
AST (U/L) & $126.8^{\#} \pm 1.81$ & $133^{\#} \pm 7.981$ & $237.4^{*} \pm 5.455$ & $129.6^{\#} \pm 2.135$ & $150.4^{\#} \pm 4.812$ \\
ALP (U/L) & $97.6^{\#} \pm 2.657$ & $103.8^{\#} \pm 2.478$ & $352.2^{*} \pm 5.286$ & $225.2^{\# *} \pm 2.871$ & $264.2^{* \# \pm 3.878}$ \\
Albumen (g/dL) & $3.972^{\#} \pm 0.063$ & $4.018^{\#} \pm 0.028$ & $3.532^{*} \pm 0.049$ & $3.82^{\#} \pm 0.072$ & $3.608^{\#} \pm 0.024$ \\
T-Protein (g/dL) & $6.638^{\#} \pm 0.031$ & $6.774^{\#} \pm 0.034$ & $6.164^{*} \pm 0.045$ & $6.258^{*} \pm 0.019$ & $6.18^{*} \pm 0.021$ \\
\hline
\end{tabular}

Data are expressed as mean $\pm \mathrm{SE}$ of 10 observations. Where G1, control group; G2, costus group; G3, Ethephon group; G4, Ethephon then costus group; G5, Ethephon then self-healing group. *Significant different from control group at P>0.05. \#Significant different from Ethephon group at $\mathrm{P}>0.05$. 
albumin levels were significantly increased in posttreated and self-healing groups when compared with Ethephon group while, Total protein levels were insignificantly increased in post-treated and self-healing groups when compared with Ethephon group (Table I).

\section{DNA fragmentation}

A comet assay was performed to assess DNA damage in liver of rats after treatment by Ethephon as compared to normal control. The results of comet assay were shown in Figures 1 and Tables II. Administration of Ethephon (G3) led to significant increase in DNA damage $(\mathrm{P}<0.05)$ that was indicated by increase in tail length, tail DNA\% and tail moment as compared to normal control (G1) and costus (G2) groups. This increased DNA damage was reduced after administration of costus as in post-treated (G4), or self-healing (G5) groups for 4 weeks with lowest damage in G4. On the other hand, no significant difference in DNA damage (tail length) was observed between normal control (G1) and costus (G2) groups.

\section{Effect of Ethephon and costus on liver histopathology}

Liver sections in male rats in the control (G1) and costus (G2) groups showed normal structure of hepatocytes where the hepatocytes are polygonal in shape with prominent round nuclei, eosinophilic cytoplasm, and few spaced hepatic sinusoids arranged in-between the hepatic cords with fine arrangement of Kupffer cells (Figures 2A and 2B). However, Liver sections in Ethephon (G3) and Ethephon self-healing (G5) groups showed hepatotoxicity manifested by marked inflammatory cells, degeneration in hepatic cords in addition to karyomegally and pyknotic nuclei indicating apoptosis, moderate fibrosis, and marked diffuse necrosis of hepatic tissue and congested blood sinusoids (Figures 2C, 2D, 2F). Liver sections in posttreated Ethephon with costus (G4) showed a moderate improvement the hepatocytes with mild degeneration, mild inflammatory cells and mild congestion of the central vein (Figure 2D).

\section{Liver PCNA expressions}

The detection of PCNA expressions in liver sections in the different groups was revealed in Table III and Figures (3A-3F). Liver sections in the control (G1) and costus (G2) groups in showed mild positive PCNA expression (Grade 1) respectively in hepatocytes nuclei (Figures 3A, 3B). Strong positive expressions for PCNA (Grade 4) in the liver sections Ethephon (G3) group were detected as compared with control (Figures 3C\&3D). Liver sections in the post-treated Ethephon with costus (G4) showed moderate positive expressions for PCNA (Grade 3) while liver sections in the Ethephon self-healing (G5) showed strong positive expressions for PCNA (Grade 4) (Figures 3E-4F). The intensity of expression of PCNA on liver after Ethephon treatment with costus was significantly decrease when compared with Ethephon (G3) or with Ethephon self-healing (G5) groups (Figures 4D-4H).

\section{DISCUSSION}

Today, a variety of plant growth regulators are being used in agriculture. Extreme use of these chemicals would certainly be accompanied with many health hazards (Abou Zeid et al., 2018). The most common used ones are ethylene, calcium carbide, ethane and Ethephon. Ethephon is a plant growth regulator that acts by releasing ethylene, directly affecting several physiological and developmental processes, such as maturation and ripening, and stimulating the construction of endogenous ethylene (Dutta, Deka, 2015; Wolterink, Inoue, Zarn, 2015).

Liver is the main target of toxicity of several compounds because most of the substances go through first-pass metabolism there. Therefore, it becomes an organ of high importance for studying the effects of different chemicals dispensed into the body. Therefore the current work aimed to study the possible modifying effects of costus extract against liver toxicity, DNA damage and proliferating PCNA alterations induced by Ethephon in male albino rats. In the current work, a significant increase in ALT, AST and ALP in treated rat with Ethephon when compared with control. Increases in plasma levels of AST and ALT serve as reliable indices of assessment of damage to the parenchymatous cells of the heart and liver, respectively (Lesley et al., 2008). Thus the observed significant increases in the activities of these enzymes are pointers to Ethephoninduced lesions in heart and liver tissues. Our results agree with Igbinaduwa and Aikpitanyi-Iduitua (2016) who find that the ALT and AST significantly increased after Calcium carbide administration to rats. Also; the 

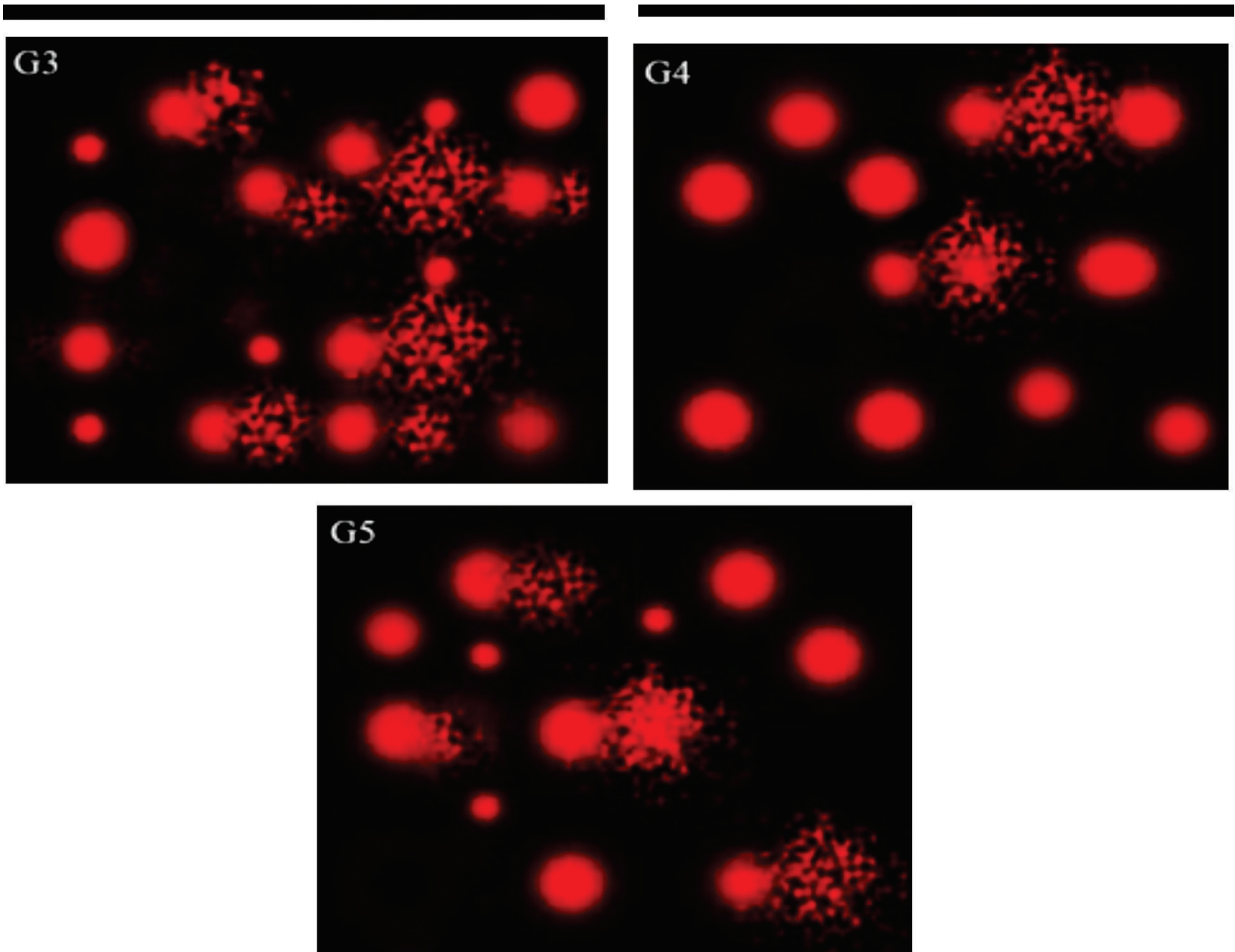

FIGURE 1 - Comet assay for DNA damage in liver tissues in different groups under study. Where G1, control group; G2, costus group; G3, Ethephon group; G4, Ethephon then costus group; G5, Ethephon then self-healing group.

TABLE II - Comet assay parameters obtained by image analysis in hepatic cells of all groups after prevention experiment

\begin{tabular}{lccccc}
\hline Group & Tailed $\%$ & Untailed $\%$ & Tails length $\boldsymbol{\mu m}$ & Tail DNA\% & Tail moment \\
\hline G1 & 1.5 & 98.5 & $1.35 \pm 0.11^{\mathrm{d}}$ & 1.38 & 1.86 \\
G2 & 2.5 & 97.5 & $1.47 \pm 0.14^{\mathrm{d}}$ & 1.54 & 2.26 \\
G3 & 28 & 72 & $9.78 \pm 0.69^{\mathrm{a}}$ & 8.65 & 84.60 \\
G4 & 13 & 87 & $4.13 \pm 0.23^{\mathrm{c}}$ & 2.81 & 11.61 \\
G5 & 18 & 82 & $6.09 \pm 0.22^{\mathrm{b}}$ & 4.85 & 29.54 \\
\hline
\end{tabular}

Data are expressed as mean $\pm \mathrm{SE}$ of 4 observations. Where G1, control group; G2, costus group; G3, Ethephon group; G4, Ethephon then costus group; G5, Ethephon then self-healing group. Different superscript letters in the same column of tail length showed significance difference at $\mathrm{P}<0.05$. 

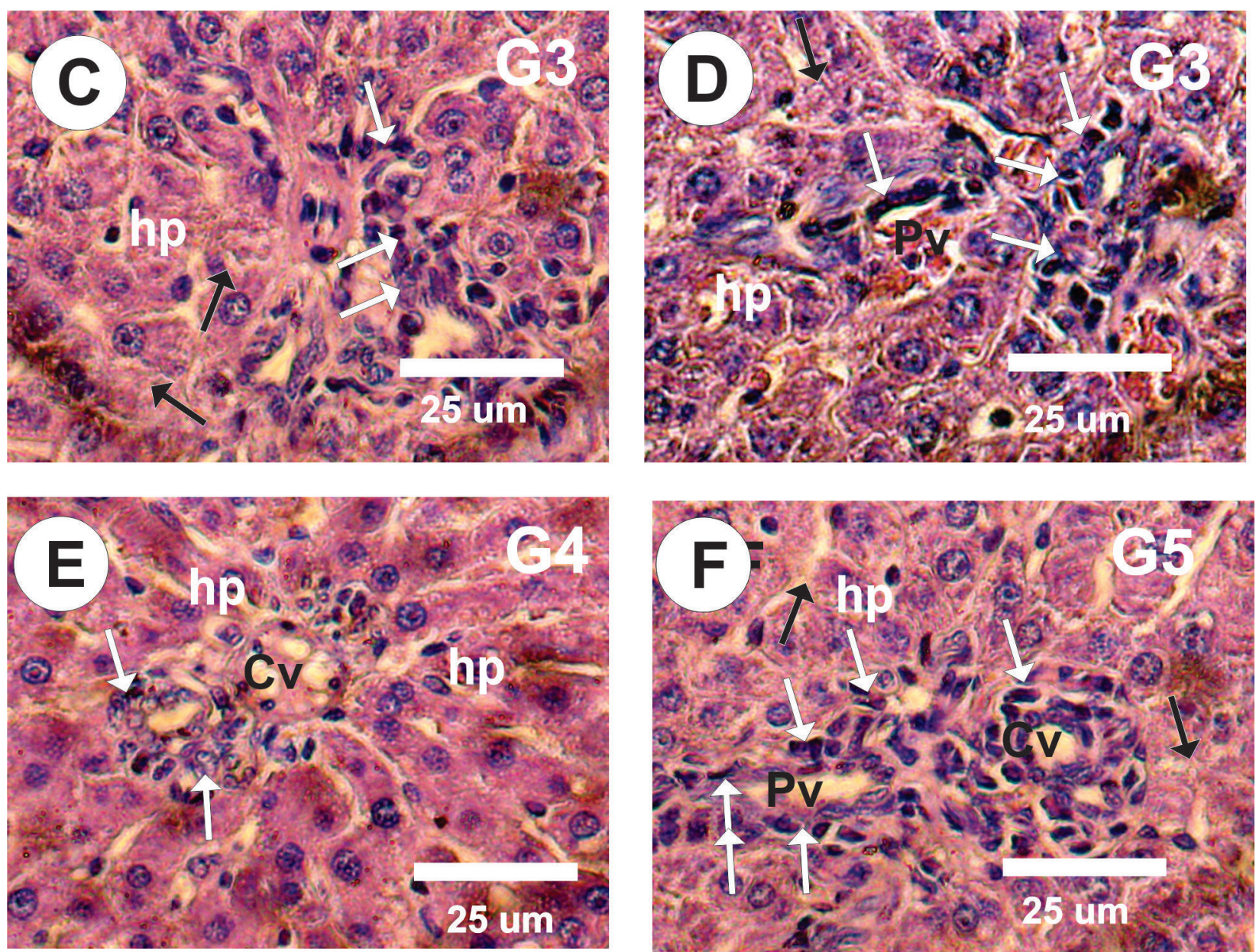

FIGURES 2)A-F) - Photomicrographs of rat liver sections stained by HE. A\&B: Liver sections in male rats in the control (G1) and costus (G2) groups showed normal structure of hepatocytes (hp) and normal central vein (Cv). C\&D\&F: Liver sections in Ethephon (G3) and Ethephon self-healing (G5) groups showed marked inflammatory cells (White arrows), degeneration in hepatic cords, and marked diffuse necrosis (Black arrows) of hepatic tissue and congested blood sinusoids. D: Liver sections in post-treated Ethephon with costus (G4) showed mild degeneration, mild inflammatory (White arrows) and mild congestion of the central vein. 

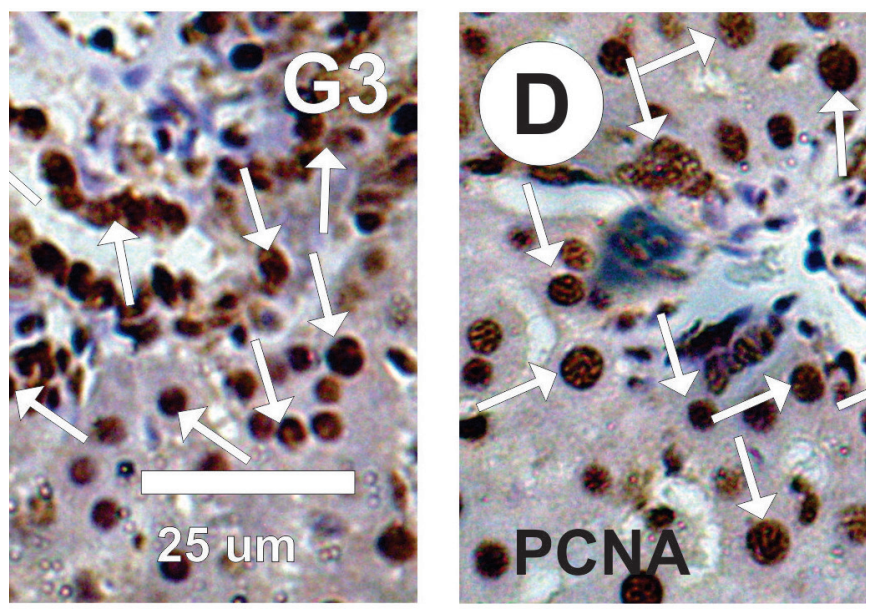

FIGURES 3(A-F) - Photomicrographs of liver sections stained with PCNA-ir in the different groups. A\&B: Liver sections in control (G1) and costus (G2) groups in showed mild positive PCNA expression (arrows) in hepatocytes nuclei. C\&D\&F: Strong positive affinity for PCNA arrows) in the liver section in treated rats with Ethephon (G3) and with Ethephon self-healing (G5). E: Liver sections in the post-treated Ethephon with costus (G4) showed moderate positive expressions (arrows) for PCNA.

current results agree with Bhadoria et al. (2015) who reported that administration of Ethephon to rats induced liver toxicity. Also; our results agrees with Uzun and Kalender (2013) who find Chlorpyrifos induced hematologic and hepatotoxic alterations in rats. Our results not agrees with Andrew et al. (2018) who reported that; no remarkable change in the levels of Aspartate aminotransferase (AST) and Alanine aminotransferase (ALT) after rats fed on diets containing calcium carbide ripened mango fruits.

Albumin and total proteins are also biomarkers of hepatotoxicity thereby showing marked decrease during liver injury. In contrast; a significant decrease in albumin in treated rat with Ethephon when compared with control. This finding is in line with the studies by El-Okazy et al. (2008) and Hussein et al. (2011) who reported oral administration of rats with plant growth regulator adversely affects liver functions and structure. Also; a significant decrease in total protein in treated rat with Ethephon when compared with control. Protein is important for structure, function, repair and, tissue building. The reduction in protein indicates increased proteolysis. A toxicant stimulating change in tissue protein leads to reduction in synthesis. This could result in shifting in nitrogen metabolism. Furthermore, inhibition of ribosomal activity results in protein degradation. This may also be a possible reason for the decrease. Treatment of Ethephon with costus improved these alterations in liver enzymes as in post-treated group. Administration of costus increased antioxidant enzyme activities in Ethephon treated rats which might be due to its ability to reduce the accumulation of free radical generation. Our results agree with Yaeesh et al. (2010) and Alnahdi, Ayaz and Elhalwagy (2016) who reported that costus (S. lappa) root extract have hepatoprotective effect against deltamethrin exposure induced liver toxicity. Bakr and Naga (2015); Eliza et al., (2009); Nitin and Khosa (2009) who reported that Costus speciosus could alter plasma enzyme (aspartate aminotransferase, alanine aminotransferase, lactate dehydrogenase, alkaline phosphatase and acid phosphatase) levels to near normal and act as hepatop2rotective activity against carbon tetrachloride.

Ethephon is phase-specific, cytotoxic drugs that can break DNA strand and leads to cell death by apoptosis (Attia 2012). In the current study; a significant increase in liver DNA fragmentation after oral administration of Ethephon while the post treated Ethephon with costus extract inhibited this liver cell damage. Extract of costus specious rhizome is rich in flavonoids. Flavonoids are very familiar to decrease oxidative stress. Oxidative stress reduction could be the reason of DNA damage inhibition. So costus extract appear as a cytoprotective agent when exposed to a free radicals scavenging activity that cause widespread damage to cell component (Labban, Mustafa, Ibrahim, 2014). 
Hepatic injury is a common pathological feature which exists in many liver diseases. Since liver fibrosis, cirrhosis and even liver cancer could result from the long existence of hepatic injury. Therefore, treatment and prevention of hepatic injury is a key to treat liver diseases clinically. In the current study; marked inflammatory cells, degeneration, moderate fibrosis, and marked diffuse necrosis of hepatic tissue and congested blood sinusoids were observed in liver sections in Ethephon and Ethephon self-healing groups. Also in the current study; a significant increase in PCNA expressions in liver tissues after Ethephon oral administration as compared with control. These findings were consistent with those of Bhadoria et al. (2015) who reported that; Ethephon administration induce histological damages in rat liver tissue. Yazar and Baydan (2008); Abd El Raouf and Girgis (2011); Bhadoria et al. (2015) who reported that; Ethephon induced hepato and nephrotoxicity. This finding is in agreement with the studies by Hussein et al. (2011) who found mild piece-meal necrosis of hepatocytes on histopathological examination of liver in rats after administering a plant growth regulator, gibberellic acid. Our result agrees with the results of Altin et al. (2011) who reported hepatocellular necrosis after administration of a high dose 4-chlorophenoxy acetic acid (4-CPA), a plant growth regulator, to rats. Treatment of Ethephon with costus improved this liver injury and the increase in PCNA expression when compared with Ethephon or self-healing Ethephon. So; the present results indicate that exposure to Ethephon has direct effects on rats liver structure and functions. Our immunohistochemical results; revealed a significant increase in PCNA on the liver after Ethephon administration and the treatment with costus improved this toxicity.

\section{CONCLUSION}

Treatment of Ethephon induces liver toxicity, injury, DNA damage and PCNA expressions. Treatment of Ethephon with costus improved these alterations as compared with Ethephon self-healing. Costus root extract treatment significantly reduces Ethephon induced hepatotoxicity in rats.

\section{REFERENCES}

Abou-Zeid S, Allam T, El-Bahrawy A, Mohamed A. Ameliorating effects of green tea on Ethephon-induced immunotoxicity and oxidative stress in mice. Int J Pharm Sci Sci Res. 2018;4(1):1-9.

Abd El Raouf A, Girgis SM. Mutagenic, teratogenic and biochemical effects of ethephon on pregnant mice and their fetuses. Glob Vet. 2011;6(3):251-257.

Alnahdi HS, Ayaz NO, Elhalwagy MEA. Prophylactic effect of cousts saussurea lappa against liver injury induced by deltamethrin intoxication. Int J Clin Exp Pathol. 2016;9(1):387-394.

Altin DT, Ozer C, Yesilkaya E, Babül A, Bideci A, Cinaz P. Effect of the plant growth regulator (4-Chlorophenoxy acetic acid) into the oxidative stress parameters in rat liver. Afr $\mathrm{J}$ Pharm Pharmacol. 2011;5(22):2498-2504.

Anant JD, Avinash BG. Modulation in serum biochemicals in European rabbit, Oryctolagus cuniculus (Linn.) exposed to ethephon. Eur J Exp Biol. 2012;2(3):794-799.

Andrew GS, Simon UT, John AU, Godwin O, Alexander I, Ikagu W. Studies on Changes in Some Haematological and Plasma Biochemical Parameters in Wistar Rats Fed on Diets Containing Calcium Carbide Ripened Mango Fruits. Int J Food Sci Nutr Engin. 2018;8(2):27-36.

Arhoghro EM, Ikeh CH, Eboh AS, Angalabiri-Owei B. Liver function of wistar rats fed the combined ethanolic leaf extract of alchornea cordifolia and costus after in paracetamolinduced toxicity. World J Pharm Res. 2015;4(1):1-12.

Attia SM. Dominant lethal mutations of topoisomerase II inhibitors etoposide and merbarone in male mice: a mechanistic study. Arch Toxicol. 2012;86(5):725-731.

Bakr E, Naga M. Potential therapeutic impacts of phyllanthus and costus aqueous extracts on CcL4 intoxicated rats. Egypt J Nutr Health. 2015;10(1):1-12.

Barrero AF, Oltra JE, Alvarez M, Raslan DS, Saude DA, Akssira M. New sources and antifungal activity of sesquiterpene lactones. Fitoterapia 2000;71(1):60-64.

Belfield A, Goldberg DM. Normal ranges and diagnostic value of serum 5' nucleotidase and alkaline phosphatase activities in infancy. Arch Dis Child. 1971;46(250):842-846.

Bhadoria P, Nagar M, Bahrioke V, Bhadoria AS. Effect of ethephon on the liver in albino rats: a histomorphometric study. Biomed J. 2015;38(5):421-427.

Bradford MM. A rapid and sensitive method for the quantification of microgram quantities of protein utilizing the principle of protein dye binding. Anal Biochem. 1976;7:248-254. 
Chang KM, Choi SI, Kim GH. Anti-oxidant activity of Saussurea lappa C.B. Clarke roots. Prevent Nutr Food Sci. 2012;17(4):306-309.

Doumas BT, Watson WA, Biggs HG. Albumin standards and the measurement of serum albumin with bromcresol green. Clin Chim Acta. 1971;31(1):87-96.

Dutta U, Deka M. Protective activity of Bambusa balcooa Roxb against repeated exposure to Ethephon induced haematological alteration in Albino rat. Toxicol Lett. $2015 ; 238(2): 84-85$.

Eliza J, Daisy $\mathrm{P}$, Ignacimuthu $\mathrm{S}$, Duraipandiyan $\mathrm{V}$. Antidiabetic and antilipidemic effect of eremanthin from Costus speciosus (Koen.)S m., in STZ induced diabetic rats. Chem Biol Interact. 2009;182(1):67-72.

El-Okazy AM. The effects of combination of Gibberellic acid -3(GA3) and ethephon (2 Chloroethyl Phosphonic Acid) (Plant Growth Regulators) on same physiological parameters in mice. J Egypt Pub Health Ass. 2008;83(1-2):67-86.

Hajam MA, Hassan GI, Bhat TA, Bhat IA, Rather AM, Parray EA. Understanding plant growth regulators, their interplay: For nursery establishment in fruits. Int $\mathrm{J}$ Chem Stud. 2017;5(5):905-910.

Hajam MA, Hassan GI, Parray E, Wani MA, Shabir A, Khan IF, Wani AW, Bhat TA, Masoodi L. Transforming fruit production by plant growth regulators. J Pharmacogn Phytochem. 2018;7(1):1613-1617.

Hussein WF, Farahat FY, Abass MA, Shehata AS. Hepatotoxic potential of Gibberellic Acid (GA3) in adult male albino rats. Life Sci J. 2011;8(3):373-383.

Hamilton AC. Medicinal plants, conservation and livelihoods. Biodivers Conserv. 2004;13(8):1477-1517.

Igbinaduwa P, Aikpitanyi-Iduitua R. Calcium carbide induced alterations of some haematological and serum biochemical parameters of wistar rats. Asian J Pharm Health Sci. 2016;6(1):1396-1400.

Irshad S, Mahmood M, Perveen F. In-vitro anti-bacterial activities of three medicinal plants using agar well diffusion method. Res J Biol Sci. 2012;2(1):1-8.

Ko SG, Kim HP, Jin DH, Bae HS, Kim SH, Park GH, et al. Saussurea lappa induces G2-growth arrest and apoptosis in AGS gastric cancer cells. Cancer Lett. 2005;220(1):11-19.

Khalid A, Uzair-ur-Rehman, Sethi A, Khilji S, Fatima U, Khan MI, et al. Antimicrobial activity analysis of extracts of Acacia modesta, Artimisia absinthium, Nigella sativa and
Saussurea lappa against Gram positive and Gram negative microorganisms. Afr J Biotechnol. 2011;10(22):4574-4580.

Labban L, Mustafa UES, Ibrahim YM. The effects of rosemary (Rosmarinus officinalis) leaves powder on glucose level, lipid profile and lipid perodoxation. Int $\mathrm{J}$ Clin Med. 2014;5(6):297-304.

Lesley AS, Josef C, Christopher HS, Harold IF, Marc F, John $\mathrm{K}$, et al. Estimating GFR using serum cystatin $\mathrm{C}$ alone and in combination with serum creatinine, A pooled analysis of 3,418 individuals with CKD. Am J Kidney Dis. 2008;51(3):395-406.

Moustafa AH, Ali EM, Moselhey SS, Tousson E, El-Said KS. Effect of coriander on thioacetamide-induced hepatotoxicity in rats. Toxicology and industrial health. 2014;30(7):621-9.

Moustakime Y, Zakaria H, Joutei K. Effect of ethephon application on the cellular maturity of Olea europaea L. and on the extractability of phenolic compounds in virgin olive oil. Chem Biol Technol Agri. 2018; 5(2):1-9.

Nitin V, Khosa RL. Evaluation of protective effects of ethanolic extract of Costus speciosus (Koenig) Sm. rhizomes on carbon tetrachloride induced hepatotoxicity in rats. Nat Prod Rad. 2009;8(2):123-126.

Pierik R, Tholen D, Poorter H, Visser EJ, Voesenek LA. The janus face of ethylene: growth inhibition and stimulation. Trends Plant Sci. 2006;11(4):176-183.

Reitman S, Frankel. Colorimetric method for aspartate and alanine aminotransferase. Am J Clin Pathol. 1957;28(1):56-63.

Saggu S, Sakeran MI, Zidan N, Tousson E, Mohan A, Rehman H. Ameliorating effect of chicory (Chichorium intybus L.) fruit extract against 4-tert-octylphenol induced liver injury and oxidative stress in male rats. Food Chem Toxicol. 2014;72:138-146.

Seki K, Hashimoto A, Kobayashi H, Kawahara Y, Yamahara J. Motility inhibitory effect on Anchusan and Jintan and its active components in Anisakis type larvae. Yakuri to Chiryo. 1991;19:265-289.

Sutar N, Garai R, Sharma US, Singh N, Roy SD. Antiulcerogenic activity of Saussurea lappa root. Int J Pharm Life Sci. 2011;2(1):516-520.

Taheri A, Cline JA, Jayasankar S, Pauls PK. Ethephoninduced abscission of 'Redhaven' peach. Am J Plant Sci. 2012;3(2):295-301.

Tousson E. Histopathological alterations after a growth promoter boldenone injection in rabbits. Toxicology and industrial health. 2016;32(2):299-305. 
Tousson E, Ali EM, Ibrahim W and Mansour MA. Proliferating cell nuclear antigen as a molecular biomarker for spermatogenesis in ptu-induced hypothyroidism of rats. Reprod Sci. 2011;18(7):679-686.

Tousson E, Bayomy MF, Ahmed AA. Rosemary extract modulates fertility potential, DNA fragmentation, injury, KI67 and P53 alterations induced by etoposide in rat testes. Biomed Pharmacother. 2018;98:769-774.

Tousson E, El-Moghazy M, Massoud A, Akel A. Histopathological and immunohistochemical changes in the testes of rabbits after injection with the growth promoter boldenone. Reproductive Sci. 2012;19(3):253-9.

Tousson E, Hafez E, Zaki S, Gad A. The cardioprotective effects of L-carnitine on rat cardiac injury, apoptosis, and oxidative stress caused by amethopterin. Environ Sci Pollut Res. 2016;23(20):20600-20608.

Tuluce Y, Celik I. Influence of subacute and subchronic treatment of abcisic acid and gibberellic acid on serum marker enzymes and erythrocyte and tissue antioxidant defense systems and lipid peroxidation in rats. Pestic Biochem Physiol. 2006;86:85-92.

Upadhyay G, Singh AK, Kumar A, Prakash O, Singh MP. Resveratrol modulates pyrogallol-induced changes in hepatic toxicity markers, xenobiotic metabolizing enzymes and oxidative stress. European journal of pharmacol. 2008;596(13):146-52.
Uzun FG, Kalender Y. Chlorpyrifos induced hepatotoxic and hematologic changes in rats: the role of quercetin and catechin. Food Chem Toxicol. 2013;55:549-556.

Wani AW, Hassan GI, Dar SQ, Baba TA, Dar MI, Amir S, et al. Influence of different phytohormones and nutrients on fruit set and chemometric attributes of apple. Vegetos. 2017;30(2):492-498.

Wolterink G, Inoue K, Zarn J. Ethephon. The Joint FAO/ WHO meeting on pesticide residues, 2015. p. 227-273.

Xiao QN, Kuo YH, Zhang Y, Barker DM, Won DJ. A tropical cyclone bogus data assimilation scheme in the MM5 3D-Var system and numerical experiments with typhoon Rusa (2002) near landfall. J Meteor Soc Japan. 2006;84(4):671-689.

Yaeesh S, Jamal Q, Shah AJ, Gilani AH. Antihepatotoxic activity of Saussurea lappa extract on D-galactosamine and lipopolysaccharide-induced hepatitis in mice. Phytother Res. 2010;2(Suppl 2):229-232.

Yashvanth S, Robinson A, BabuKS, Naidu VGM, Vishnuvardhan MVPS, Ramakrishna S, et al. Anti-inflammatory and cytotoxic activity of chloroform extract of roots of Saussurea lappa Clarke. J Pharm Res. 2010;3(8):1775-1778.

Yazar S, Baydan E. The subchronic toxic effects of plant growth promoters in mice. Vet Fak Derg. 2008;55:17-21.

Received for publication on $29^{\text {th }}$ June 2018 Accepted for publication on $23^{\text {th }}$ September 2018 